\title{
Обгрунтування оптимальних параметрів відокремлення монолітів природного каменю від масиву алмазно-канатними установками 3 метою зменшення втрат
}

Під час відокремлення монолітів від масиву алмазно-канатними установками зберігається його цілісність, але разом з цим виникають супутні проблеми та питання, такі як вибір оптимальних розмірів моноліту і кута буріння для заведення канату, або які механізми чи пристосування використовувати при відділенні моноліту від масиву. Процес відокремлення моноліту від масиву алмазними канатними установками здебільшого супроводжується виникненням кількісних втрат каменю, на які впливають такі параметри: кількість площин оголення моноліту, розміри моноліту, який вилучається, абсолютний діаметр буру, товщина алмазного канату. Якісні втрати під час використання алмазно-канатних пил майже відсутні. Однак на їх виникнення впливають такі чинники: відхилення канату від заданої плошини пропилу, нерівномірне зношування алмазних втулок $і$ зміна товщчини алмазного шару в результаті його зношування під час різання.

Ключові слова: алмазно-канатні установки; кількісні втрати; якісні втрати; оптимальний діаметр буріння; геометричні параметри моноліту.

Постановка завдання. На підрахунок втрат декоративного каменю під час його відокремлення від масиву в першу чергу впливає діаметр свердловини та геометричні параметри моноліту. При цьому необхідно враховувати можливе відхилення бурового інструменту від проєктної осі свердловини через великий опір породи бурінню і неточність установки бура.

Аналіз останніх досліджень та публікацій, на які спираються автори. Аналіз сучасного стану видобування декоративного каменю засвідчує, що основними причинами низької конкурентоспроможності блоків вітчизняних підприємств є їх низька якість та невідповідність світовим стандартам, що зумовлено недосконалістю технології видобування блоків та їі негативним впливом на технологічні, фізико-технічні та декоративні властивості сировини [5-7].

Видобування блоків високоміцних порід залишається все ще трудомістким процесом і повністю не забезпечує на відповідному рівні їх якісні показники, а каменедобувна галузь України все ще відчуває великий дефіцит блоків декоративного каменю.

Ефективність каменеобробного виробництва, матеріалоємність продукції, що випускається, втрати сировини під час її переробки на продукцію багато в чому залежать від таких якісних показників блоків, як їх розміри, монолітність породи, нерівності відколу лицьових поверхонь, кількість відбитих кутів і ребер [1-5].

Одним з головних факторів, який суттєво впливає на якість блочної сировини, є технологія видобування природного каменю. Алмазно-канатна технологія видобування природного каменю за останні десятиріччя отримала широке розповсюдження на вітчизняних кар'єрах. Проте питання ефективного використання цієї технології для відокремлення монолітів від масиву природного каменю залишається відкритим.

Метою статті $є$ обгрунтування оптимального діаметра свердловини для заведення канату при відокремленні монолітів від масиву алмазно-канатною установкою 3 метою зменшення втрат декоративного каменю.

Викладення основного матеріалу. На сучасному етапі каменедобувної промисловості найперспективнішим технологічним напрямом видобування декоративного блочного каменю $\epsilon$ використання каменерізальних технологій, за яких відокремлення монолітів від масиву і іх поділ на товарні блоки відбувається за допомогою канатних установок. Канатопильні установки характеризуються високою продуктивністю, простотою конструкції, можливістю використання при видобуванні каменю в складних геологічних умовах та складній геометрії вибою.

Наявність пластових тріщин у масиві не тільки збільшує продуктивність процесу видобування, але й сприяє зменшенню кількісних втрат сировини. Якщо родовище характеризується відсутністю первинних природних пластових тріщин, то здебільшого для відокремлення моноліту від масиву здійснюють два 
вертикальних і один горизонтальний пропили. Буріння, що призначене для заведення алмазного канату на лабрадоритових кар’єрах, передбачає створення двох свердловин, які взаємно перетинаються.

Характерною особливістю розпилювання порід високої міцності алмазно-канатним інструментом $\epsilon$ поява одностороннього зношування алмазних втулок, шо не спостерігається при розпилюванні мармуру та подібних до нього порід середньої міцності. Насамперед, це пояснюється тим, що під час розпилювання високоміцних порід потрібно прикладати більше зусилля натягу робочого інструменту в результаті чого робочому канату не вистачає пружних зусиль і він у процесі різання не прокручується навколо своєї вісі. Внаслідок одностороннього зношування канату площина поверхні блоку викривляється і набуває хвилеподібної або дугоподібної форми. Описати математично об'єм втрат, які виникають внаслідок перерахованих вище чинників, практично неможливо через непередбачуваність відхилення робочого інструменту від площі пропилу і тим самим спотворення форми поверхні блоку.

В процесі вилучення моноліту 3 масиву з використанням алмазно-канатних установок інструмент 3 часом спрацьовується, тобто товщина алмазного шару втулок, що його містять, зменшується і тим самим змінюється товщина пропилу. Це в свою чергу обумовлює відхилення поверхні моноліту від вертикальної площини пропилу.

Об'єм кількісних втрат сировини при відокремленні моноліту від масиву алмазно-канатними установками в першу чергу залежить від площі пропилу, тобто геометричних параметрів моноліту, що відокремлюється від масиву.

Кількісні втрати каменю при відокремленні моноліту від масиву за наявності в масиві пластової природної тріщини можна обчислити за такою формулою:

де $S_{p}$ - площа різу, м²;

$$
V_{\kappa .6 .}=\sum_{i=1}^{k} S_{p} \cdot b+\sum_{i=1}^{n} S_{c} \cdot L_{c},\left(\mathrm{M}^{3}\right)
$$

$k$ - кількість площин пропилу, шт;

$b$ - ширина щілини, м;

$S_{c}$ - площа свердловини, яка пробурюється для заведення канату, $\mathbf{m}^{2}$;

$L_{c}-$ довжина свердловини, яка пробурюється для заведення канату, м;

$n$ - кількість свердловин, шт.

Ширину щілини можна визначити за такою формулою:

$$
b=d_{k}+t,(\mathrm{MM})
$$

де $d_{k}-$ діаметр циліндричних алмазних втулок, мм;

$t$ - ширина зазору між різальним канатом і бічними сторонами блоку, $\mathrm{t}=0,5 \mathrm{mм}$.

На теперішній час здебільшого використовують втулки діаметром 10,5, 11 і 11,5 мм.

Загальні кількісні втрати сировини, що обчислюються для одного відокремленого блоку, можна визначити за формулою:

де $H$ - висота пропилу, м;

$$
V_{k}=\frac{H \cdot(L+B) \cdot b}{2}+\frac{\pi D^{2}}{8} \cdot\left(L^{\prime}+B^{\prime}+H^{\prime}\right),\left(\mathrm{M}^{3}\right)
$$

$L$ - довжина пропилу, м;

$B$ - ширина пропилу, м;

$b$ - ширина щілини, м;

$D$ - діаметр буріння, м;

$L^{\prime}$ - довжина повздовжньої горизонтальної свердловини, м;

$B^{\prime}$ - довжина поперечної горизонтальної свердловини, м;

$H^{\prime}$ - довжина вертикальної свердловини на всю висоту моноліту, м.

Висоту пропилу можна обрахувати за формулою:

$$
H=H_{M}-D,(\mathrm{M})
$$

де $H_{м}$ - висота моноліту, м.

Довжину пропилу можна обчислити за формулою:

$$
L=L_{M}-D,(\mathrm{M})
$$

де $L_{M}$ - довжина моноліту, м.

Ширину пропилу можна визначити за формулою:

$$
B=B_{M}-D,(\mathrm{M})
$$

де $B_{M}$ - ширина моноліту, м.

При цьому довжина повздовжньої горизонтальної свердловини відповідає довжині пропилу, а довжина поперечної горизонтальної свердловини дорівнює ширині пропилу.

Отже, формулу 3 можна зобразити в такому вигляді:

$$
V_{k}=\frac{\left(H_{M}-D\right) \cdot\left(L_{M}+B_{M}-2 D\right) \cdot\left(d_{k}+t\right)}{2}+\frac{\pi D^{2}}{8} \cdot\left(L_{M}+B_{M}+H_{M}-D\right),\left(\mathrm{M}^{3}\right) .
$$


Під час підрахунку якісних втрат необхідно враховувати можливе відхилення бурового інструменту від проєктної осі свердловини через великий опір породи бурінню і неточність установки бура.

Величину відхилення бурового інструменту від заданої площини на один погонний метр буріння можна визначити за формулою:

$$
\text { Д }=\frac{\sigma_{c m}}{d_{c B}},
$$

де $\sigma_{c m}-$ межа міцності породи на стиск, МПа;

$d_{c B}-$ діаметр свердловини, м.

Ширина зони зони можливих втрат може бути визначена з формули:

$$
B_{\text {м.в. }}=d_{c 6}+2 Д \cdot H,(\mathrm{M})
$$

де $H$ - проєктна довжина свердловини, яка відповідає висоті моноліту, м.

Кінцеву ширину пропилу можна визначити, за формулою:

$$
d=b-e,(\mathrm{M})
$$

де $b$ - початкова ширина пропилу, м;

$e$ - величина відхилення площини пропилу від проєктної осі пропилу, м

Знаючи питому витрату алмазного шару, можна визначити величину відхилення площини пропилу від проєктної осі пропилу:

$$
e=q \cdot S_{p},(\mathrm{M})
$$

де $q$ - питома витрату алмазного шару ( $q$ приймається 0,033$),$ мм/м²;

$S_{p}$ - площа різу, м $^{2}$.

Об’єм якісних втрат, які виникають від зміни форми поверхні бічної грані, визначається з формули:

$$
V_{g}=\frac{1}{2}\left(H_{M}-D\right) \cdot\left(B_{M}-D\right) \cdot e^{/}+\frac{1}{2}\left(H_{M}-D\right) \cdot\left(L_{M}-D\right) \cdot e^{/ /},\left(\mathrm{M}^{3}\right)
$$

де $D$ - діаметр буріння, ${ }^{2}$;

$H_{M}$ - висота моноліту, м;

$B_{м}$ - ширина моноліту, м;

$L_{M}$ - довжина моноліту, м;

$e^{\prime}$ - величина відхилення бічної грані в результаті виконання поперечного пропилу, м;

$e^{\prime \prime}$ - величина відхилення бічної грані в результаті виконання повздовжнього пропилу, м

Знаючи величину відхилення бічної грані $e$ (формула 11) та питому витрату алмазного шару $q$ (приймаємо значення 0,33), підставляємо їх в попередній вираз, тоді формула 12 набуває вигляду:

$$
V_{g}=\frac{1}{2}\left(H_{M}-D\right)^{2} \cdot\left(B_{M}-D\right)^{2} \cdot q+\frac{1}{2}\left(H_{M}-D\right)^{2} \cdot\left(L_{M}-D\right)^{2} \cdot q,\left(\mathrm{M}^{3}\right) .
$$

Одним із важливих завдань проведених досліджень було отримання оптимальних параметрів відокремлення монолітів від масиву за допомогою алмазного канату, за яких якісні та кількісні витрати були б мінімальними. Таким параметром є діаметр свердловини, яку пробурюють 3 метою заведення канату в масив.

При проведенні даних досліджень було використано бурові верстати з різними діаметрами бурових штанг. Дані проведеного досліду наведено в таблиці 1.

Залежність утворення об'єму кількісних втрат від обраного діаметра свердловини зображено за

\begin{tabular}{|c|c|c|c|c|c|c|c|c|}
\hline \multicolumn{3}{|c|}{ Параметри моноліту } & \multirow{2}{*}{$\begin{array}{l}\text { Діаметр } \\
\text { буріння }\end{array}$} & \multirow{2}{*}{$\begin{array}{c}\text { Діаметр } \\
\text { канату }\end{array}$} & \multirow{2}{*}{$\begin{array}{c}\text { Ширина } \\
\text { зазору }\end{array}$} & \multirow{2}{*}{$\begin{array}{c}\text { Питомі } \\
\text { витрати } \\
\text { алмазного } \\
\text { шару } \\
\end{array}$} & \multirow{2}{*}{$\begin{array}{c}\text { Об'єм } \\
\text { кількісних } \\
\text { втрат }\end{array}$} & \multirow{2}{*}{$\begin{array}{c}\text { Об’єм } \\
\text { яісних } \\
\text { втрат }\end{array}$} \\
\hline висота & ширина & довжина & & & & & & \\
\hline $\mathrm{H}_{\mathrm{M}}, \mathrm{M}$ & $\mathrm{B}_{\mathrm{M}}, \mathrm{M}$ & $\mathrm{L}_{\mathrm{M}}, \mathrm{M}$ & $\mathrm{D}, \mathrm{M}$ & $\mathrm{d}_{\mathrm{K}}, \mathrm{M}$ & $\mathrm{t}, \mathrm{M}$ & $\mathrm{q}, \mathrm{M} / \mathrm{M}^{2}$ & $\mathrm{~V}_{\mathrm{K}}, \mathrm{M}^{3}$ & $\mathrm{~V}_{\mathrm{g}}, \mathrm{M}^{3}$ \\
\hline 5 & 2 & 6 & 0,06 & 0,011 & 0,0005 & 0,00003 & 0,21946 & 0,01209 \\
\hline 5 & 2 & 6 & 0,07 & 0,011 & 0,0005 & 0,00003 & 0,22508 & 0,01199 \\
\hline 5 & 2 & 6 & 0,08 & 0,011 & 0,0005 & 0,00003 & 0,23540 & 0,01184 \\
\hline 5 & 2 & 6 & 0,09 & 0,011 & 0,0005 & 0,00003 & 0,23934 & 0,01177 \\
\hline 5 & 2 & 6 & 0,10 & 0,011 & 0,0005 & 0,00003 & 0,24797 & 0,01167 \\
\hline 5 & 2 & 6 & 0,12 & 0,011 & 0,0005 & 0,00003 & 0,26823 & 0,01149 \\
\hline
\end{tabular}
допомогою графіка (рис. 1), який побудований на основі отриманих результатаів при проведенні досліджень (табл. 1).

Таблиия 1

Показники, які використовувалися для визначення кількісних і якісних втрат декоративного каменю Невирівського родовища лабрадориту залежно від обраного діаметра бурової штанги верстата 


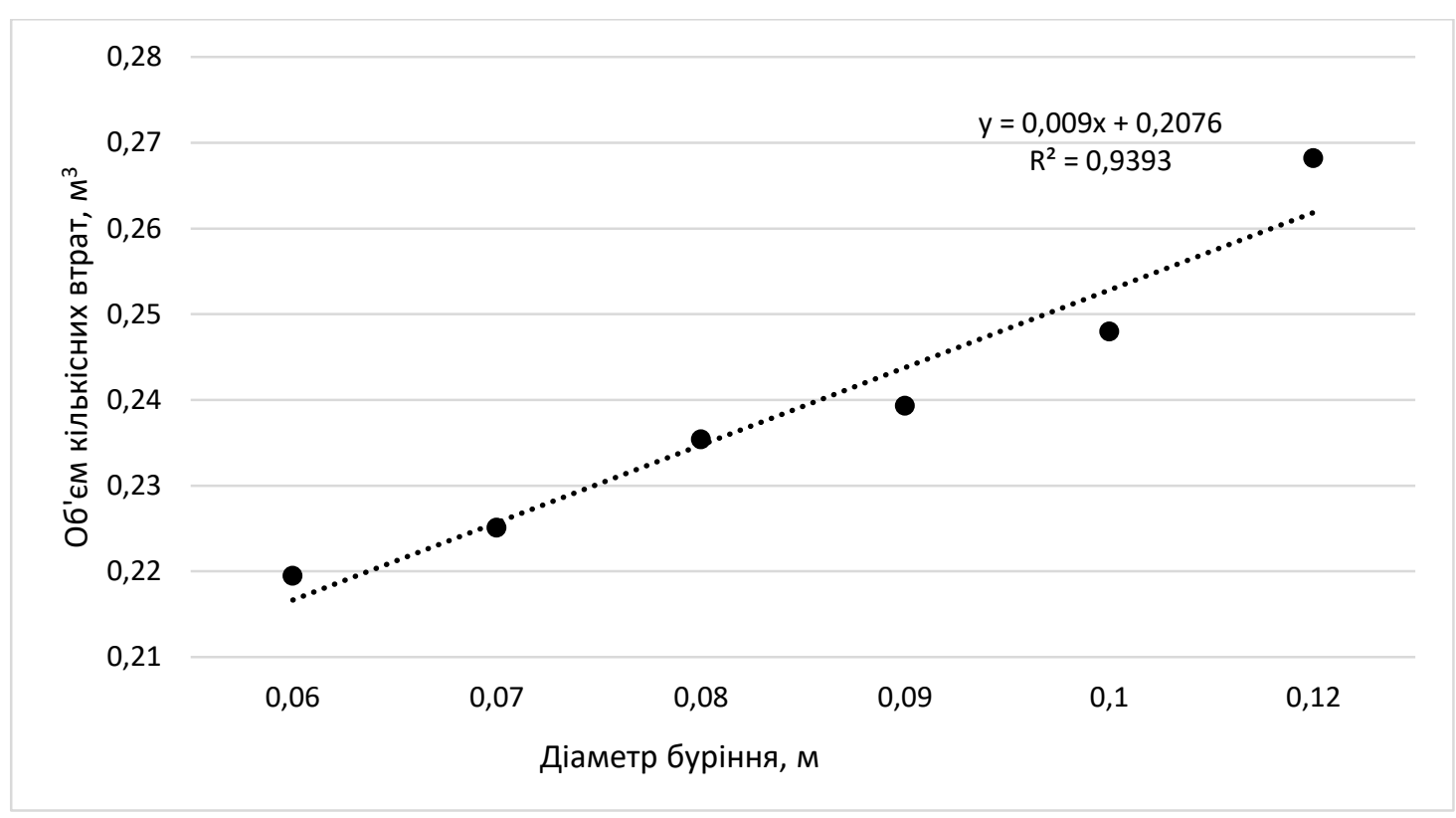

Рис. 1. Залежність об 'єму кількісних втрат від діаметра буріння

Як видно з рисунка 1 об’єм кількісних втрат знаходиться в пропорційній залежності від величини зміни діаметра штанги бурового верстата і описується рівнянням такого вигляду:

$$
V_{k}=0,009 D+0,208 \text {. }
$$

При цьому коефіцієнт апроксимації $-\mathrm{R}^{2}=0,94$.

На рисунку 2 показано залежність утворення якісних втрат декоративного каменю від зміни діаметра бурового інструменту.

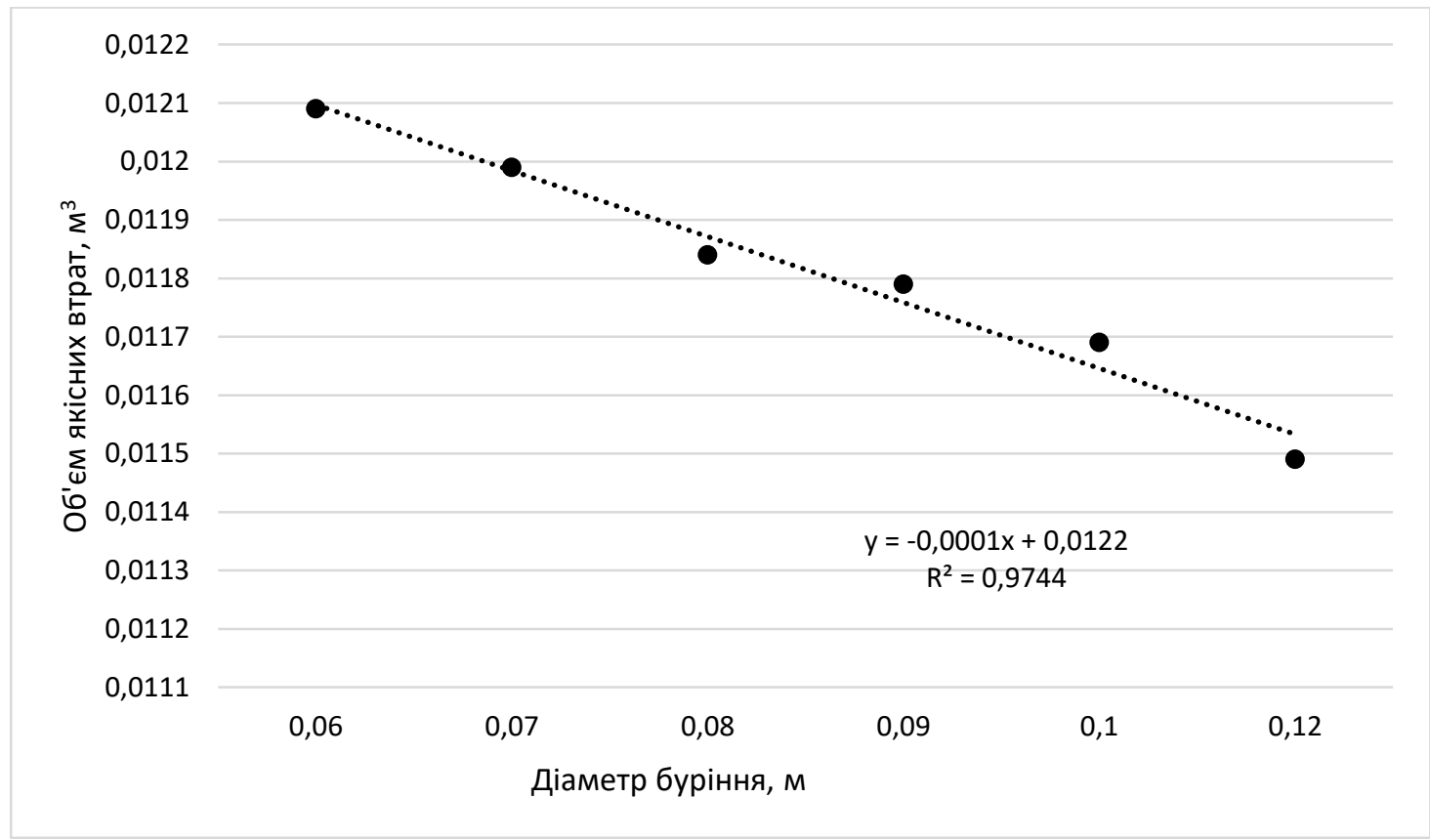

Рис. 2. Залежність об’'єму якісних втрат від діаметра буріння

3 рисунка 2 видно, що якісні втрати знаходяться в обернено пропорційній залежності від діаметра бурових свердловин і ця залежність описується рівнянням:

$$
V_{k}=0,0122-D \cdot 10^{-4} \text {. }
$$

При цьому коефіцієнт детермінації $-\mathrm{R}^{2}=0,97$.

Порівняльний графік (рис. 3) дає змогу визначити оптимальні параметри бурової свердловини на основі мінімізації кількісних і якісних втрат декоративного каменю. Оптимальність діаметра свердловини визначалася графічним способом по перекриттю зон в інтервалах мінімальних значень якісних і кількісних втрат каменю. 


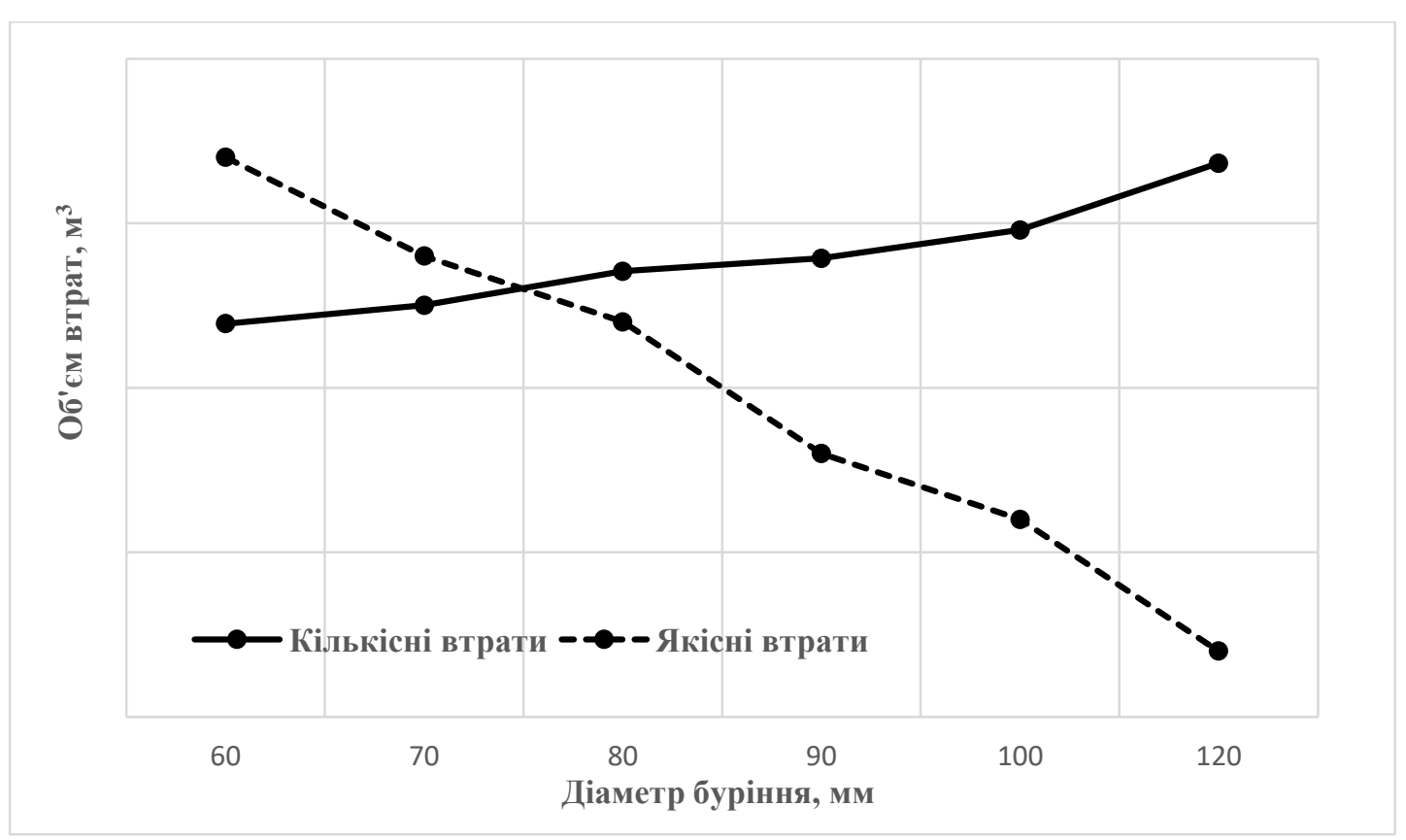

Рис. 3. Визначення оптимального діаметра свердловини за співідношенням об' ємів якісних і кількісних втрат

Як видно з рисунка 3 оптимальне значення діаметра свердловини знаходиться в межах від 70 до 80 мм, а для Невирівського родовища лабрадориту це значення становить 75 мм. Також результати досліджень доводять, що зі зменшенням товщини робочого інструменту під час вирізання монолітів 3 масиву кількісні втрати змешуються, але при цьому збільшується рівень розубожіння за рахунок відхилення бічних граней моноліту від перпендикулярності.

Висновки та перспективи подальших досліджень. Виконані розрахунки дають змогу стверджувати, що зі збільшенням сумарної площини пропилу під час використання канатних каменерізальних установок спостерігається збільшення як кількісних, так і якісних втрат декоративного каменю, причому залежність має прямо пропорційний характер. Однак геометричні параметри моноліту більше впливають на виникнення кількісних втрат каменю, в той час як на виникнення якісних втрат більше впливає характер зношуваності алмазних втулок під час різання каменю і можливе відхилення бурової штанги верстата від проєктної осі свердловини. Оптимізація діаметра бурової свердловини дозволяє мінімізувати як кількісні, так і якісні втрати декоративного каменю.

\section{Список використаної літератури:}

1. Бакка М.T. Класифікація втрат і збіднення облицювальних гранітів / М.Т. Бакка, О.О. Кісєль // Вісник ЖДТУ. Технічні науки. - Житомир, 2005. - № 33 (II). - С. 133-135.

2. Бакка H.T. Разработка технологии и комплексов оборудования добычи блоков из высокопрочных трещиноватых пород : дис. .... докт. техн. наук / Н.Т. Бакка. - Житомир, 1986. - 378 с.

3. Кісєль О.О. Дослідження закономірностей утворення і формування втрат природного каменю при його видобуванні / О.О. Кісель // Проблеми природокористування, сталого розвитку та техногенної безпеки регіонів : Матеріали третьої міжнародної науково-практичної конференції. - Дніпропетровськ, 2005. - С. 123-124.

4. Кісєль O.O. Розробка методичних основ оцінки і обліку втрат декоративного каменю при його видобуванні : дис. ... канд. техн. наук / О.О. Кісєль. - Житомир, 2007. - 200 с.

5. Котенко B.B. Перспективи розвитку канатних каменерізальних технологій на кар'єрах з видобування блочного каменю з міцних порід / В.В. Котенко // Вісник ЖІТІ / Технічні науки. - № 22 (I). - Житомир, 2002. - С. 163-165.

6. Синельников О.Б. Природный облицовочный камень. Часть 1. Облицовочные камни : учебное пособие / О.Б. Синельников. - М. : МГГУ, 2000. - 362 с.

7. Смирнов А.Г. Добыча и обработка природного камня : справочник / А.Г. Смирнов. - М. : Недра, 1990. -445 с.

8. Башинський C.I. Оптимізація конструкції втулки алмазного канату для високоміцних порід облицювального каменю / С.I. Башинський, В.В. Котенко, С.В. Кальчук // Восточно-Европейский журнал передовых технологий. $-2014 .-6 / 7$ (72). - С. 55-60.

9. Башинський C.I. Диференціальні залежності силових параметрів роботи алмазного канату при видобуванні блоків твердих порід облицювального каменю / С.І. Башинський // Вісник ЖДТУ. - Житомир, 2013. № 2 (64). - C. 116-120.

10. Чапська K.P. Визначення жорсткості алмазного канату на кручення з метою уточнення фізико-математичної моделі процесу розпилювання природного каменю / К.P. Чапська, С.О. Дубченко, С.I. Башинський // Тези Всеукраїнської науково-практичної on-line конференції аспірантів, молодих учених та студентів, присвяченої Дню науки. Т.1. - Житомир : ЖДТУ, 2014. - С. 3-4. 
11. Башинський C.I. Дослідження процесу різання природного облицювального каменю алмазним канатом / C.I. Башинський // Технологический аудит и резервы производства. - Харків, 2013. - № 4/2 (12). - С. 34-39.

\section{References:}

1. Bakka, M.T. and Kisjel', O.O. (2005), «Klasyfikacija vtrat i zbidnennja oblycjuval'nyh granitiv», Visnyk ZhDTU. Tehnichni nauky, Vol. 33 (II), pp. 133-135.

2. Bakka, N.T. (1986), «Razrabotka tekhnologii i kompleksov oborudovaniya dobychi blokov iz vysokoprochnykh treshchinovatykh porod»,D.Sc. Thesis of dissertation, Zhitomir, $378 \mathrm{p}$.

3. Kisjel', O.O. (2005), «Doslidzhennja zakonomirnostej utvorennja i formuvannja vtrat pryrodnogo kamenju pry jogo vydobuvanni», Proceedings 3d Int. Symp. «The problems of the deposits using, sustainability and the technical safety of the regions», Dnipropetrovs'k, pp. 123-124.

4. Kisjel', O.O. (2007), «Rozrobka metodychnyh osnov ocinky i obliku vtrat dekoratyvnogo kamenju pry jogo vydobuvanni:», Abstract of Ph.D. dissertation, Zhytomyr, 200 p.

5. Kotenko, V.V. (2002), «Perspektyvy rozvytku kanatnyh kamenerizal'nyh tehnologij na kar'jerah z vydobuvannja blochnogo kamenju z micnyh porid», Visnyk ZhITI/ Tehnichni nauky, Vol. 22 (I), Zhytomyr, pp. 163-165.

6. Sinel'nikov, O.B. (2000) Prirodnyi oblitsovochnyi kamen'. Chast' 1. Oblitsovochnye kamni, uchebnoe posobie, MGGU Publ., Moscow, 362 p.

7. Smirnov, A.G. (1990), Dobycha i obrabotka prirodnogo kamnya, spravochnik, Nedra Publ., Moscow, 445 p.

8. Bashyns'kyj, S.I., Kotenko, V.V. and Kal'chuk, S.V., (2014), «Optymizacija konstrukcii' vtulky almaznogo kanatu dlja vysokomicnyh porid oblycjuval'nogo kamenju», Vostochno-Evropeiskii zhurnal peredovykh tekhnologii, Vol. 6/7 (72), pp. 55-60.

9. Bashyns'kyj, S.I. (2013), «Dyferencial'ni zalezhnosti sylovyh parametriv roboty almaznogo kanatu pry vydobuvanni blokiv tverdyh porid oblycjuval'nogo kamenju», Visnyk ZhDTU, Vol. 2 (64), pp. 116-120.

10. Chaps'ka, K.R., Dubchenko, Je.O. and Bashyns'kyj, S.I. (2014), «Vyznachennja zhorstkosti almaznogo kanatu na kruchennja z metoju utochnennja fizyko-matematychnoi' modeli procesu rozpyljuvannja pryrodnogo kamenju», Tezy Vseukrai'ns'koi' naukovo-praktychnoi' on-line konferencii' aspirantiv, molodyh uchenyh ta studentiv, prysvjachenoi' Dnju nauky, Part 1, Zhytomyr, pp. 3-4.

11. Bashyns'kyj, S.I. (2013), «Doslidzhennja procesu rizannja pryrodnogo oblycjuval'nogo kamenju almaznym kanatom», Tekhnologicheskii audit i rezervy proizvodstva, Vol. 4/2 (12), pp. 34-39.

Меринов Роман Романович - студент гірничо-екологічного факультету Державного університету «Житомирська політехніка».

Наукові інтереси:

- видобування стінового каменю та блоків;

- технології відкритих гірничих робіт.

Остафійчук Неля Миколаївна - старший викладач кафедри розробки родовищ корисних копалин ім. проф. Бакка М.Т. Державного університету «Житомирська політехніка».

http://orcid.org/0000-0002-7238-706X.

Наукові інтереси:

- геолого-економічна оцінка родовищ пегматитів;

- пошуки та розвідка родовищ каменебарвної сировини.

Колодій Марина Анатоліївна - старший викладач кафедри розробки родовищ корисних копалин ім. проф. Бакка М.Т. Державного університету «Житомирська політехніка».

http://orcid.org/0000-0001-5133-552X.

Наукові інтереси:

- технічна гідравліка;

- гірничі машини та комплекси.

Котенко Володимир Володимирович - кандидат технічних наук, доцент, декан гірничо-екологічного факультету Державного університету «Житомирська політехніка».

http://orcid.org/0000-0001-8764-1692.

Наукові інтереси:

- процеси гірничого виробництва;

- контроль та оцінка втрат сировини на гірничих підприємствах.

Башинський Сергій Іванович - кандидат технічних наук, доцент кафедри розробки родовищ корисних копалин ім. проф. Бакка М.Т. Державного університету «Житомирська політехніка».

http://orcid.org/0000-0002-2945-7683.

Наукові інтереси:

- технологія алмазно-канатного розпилювання природного каменю;

- моделювання процесів гірничого виробництва. 